\title{
EFFECT OF PHOSPHATE DISSOLVING BACTERIA INOCULATION AND PHOSPHORUS FERTILIZATION ON GROWTH, YIELD AND SEED QUALITY OF SOYBEAN
}

\section{FATMA A. ABDO}

Crop Physiology Res.Dept., Field Crops Res. Inst., ARC, Giza

(Manuscript received 22 Octber 2007)

\section{Abstract}

The present investigation was carried out at Giza Experimental Station, Agricultural Research Center (ARC), during the two successive summer seasons, 2005 and 2006 in order to investigate the influence of seed inoculation with phosphate dissolving bacteria (Phosphorein) under different levels of applied phosphorus $(0,5.63,11.25$ and $22.50 \mathrm{~kg}$ $\mathrm{P}_{2} \mathrm{O}_{5}$ /feddan $(0,25,50$ and $100 \%$ of the recommended dose, respectively) on growth, anatomical structure, photosynthetic pigments and total sugars of leaves, yield, yield components, and seed quality of soybean cv.'Giza 35'.

Results indicated that increasing the level of phosphorus fertilizer from 25 to $100 \%$ of the recommended dose (22.5 kg $\mathrm{P}_{2} \mathrm{O}_{5}$ /fed.) caused significant increases in plant height, number of branches/plant, shoot dry weight/plant, number of pods/plant and seed yield /fed in both seasons. Likewise, leaf area index at 45, 60, 75 and 90 days after sowing as well as crop growth rate at $60-75$ and $75-90$ days after sowing were significantly improved with increasing the level of applied phosphorus in both seasons. Appreciable increases in photosynthetic pigments and total sugars in leaves were also observed. In addition, seed crude protein, total carbohydrates and phosphorus contents were increased with increasing applied phosphorus in the second season.

Phosphorein biofertilizer treatment was superior to the control treatment by 13.1 and $12.7 \%$ for plant height, 20.4 and $13.7 \%$ for number of branches/plant, 11.4 and $11.1 \%$ for dry weight of shoot/plant, 9.2 and $9.6 \%$ for number of pods/plant and 10.4 and $10.6 \%$ for seed yield /feddan in the first and second seasons, respectively. Likewise, leaf area index and crop growth rate were significantly increased at all studied growth stages due to biofertilization treatment in both seasons. The increases in photosynthetic pigments and total sugars in leaves of soybean due to biofertilization treatment were $14.6 \%$ for chl a, $20.4 \%$ for chl b, $16.1 \%$ for ch (a+b), $18.6 \%$ for carotenoides and $16.7 \%$ for total sugars in 2006 season. Meanwhile, biofertilization increased seed crude protein, total carbohydrates and phosphorus contents by $7.4,4.7$ and $5.2 \%$, respectively in 2006 season.

The application of $11.25 \mathrm{Kg} \mathrm{P} \mathrm{P}_{5} /$ fed $(50 \%$ of the recommended rate of phosphorus fertilizer) along with seed inoculation with phosphorein biofertilizer gave almost similar results to those obtained from the application at the recommended rate ( $22.5 \mathrm{~kg} \mathrm{P}_{2} \mathrm{O}_{5} /$ fed ) alone, indicating the 
EFFECT OF PHOSPHATE DISSOLVING BACTERIA INOCULATION AND PHOSPHORUS FERTILIZATION ON GROWTH, YIELD AND SEED QUALTTY OF SOYBEAN

possibility of reducing the amounts of chemical fertilizer presently used in soybean fields.

Key words: Soybean, Phosphorus fertilization, Biofertilizer, Phosphate dissolving bacteria, Growth, Photosynthetic pigments, Anatomy, Yield, Seed quality.

\section{INTRODUCTION}

Soybean [Glycine $\max$ (L.) Merrill] is one of the most important industrial crops worldwide. Seeds contain approximately $40 \%$ protein and $20 \%$ edible oil. Soy meal is used for animal feed. Phosphorus fentilization is essential for field crop production, especially legumes (Kabesh et al., 1989 and Abd El-Lateef et al., 1998 on soybean, Hessien, 2000 and Abdo 2003 on mungbean. In this connection, Kabesh et al., 1989 found soil application of phosphorus to soybean on sandy loam soil significantly increased plant height, number of leaves, and dry weight of stems, leaves and whole plant. Abdel-Aziz and El-Shafie (2005) found that spraying soybean plants with 1.5 or $3 \% \mathrm{P}_{2} \mathrm{O}_{5}$ significantly increased plant height, number of branches/plant and leaf area index at 50, 71 and 92 days after sowing (DAS) compared to control. However, the values of net assimilation rate (NAR) and crop growth rate (CGR) were decreased at the second period (71-92 DAS) compared with the first one (50-71 DAS). Moreover, increasing the levei of $-\mathrm{P}$ from 0.0 up to $3 \% \mathrm{P}_{2} \mathrm{O}_{5}$ significantly increased seed yield/fed, number and weight of pods/plant as well as straw and seed weight/plant. However, 100- seed weight and straw yield/feddan were not significantly affected. They also found that foliar spray of $3 \% \mathrm{P}_{2} \mathrm{O}_{5}$ increased total chlorophyll of leaves and protein content of seeds, while seed oil content was decreased.

Many investigators demonstrated that inoculation with phosphate dissolving microorganisms might be comparable to phosphorus application. In this respect, ElKalla et al. (1997) found that the application of biofertilizer (phosphorein) to faba bean increased plant height, number of branches and pods/plant, number of seeds/pod, seed yield/plant, 100- seed weight, seed yield/fed. as well as seed protein content. Abd El-Lateef et al. (1998) mentioned that biofertilization increased soybean seed yield by $20.4 \%$ over the control treatment. However, seed oil content showed a reversible trend. In addition, the highest seed protein content was recorded from the application of $15 \mathrm{~kg} \mathrm{P}_{2} \mathrm{O}_{5}$ /fed. Generally, the use of biofertilizer improved soil fertility and enriched its biological ${ }^{*}$ activity. Likewise, Abdo (2003) stated that inoculating mungbean seeds with a biofertilizer resulted in significant increases in plant height, number of branches, number of leaves, shoot dry weight, number of pods, number of seeds and seed yield/plant as well as leaf area index seed, straw and protein 
yields/fed, percentage of total carbohydrate, total lipids and phosphorus in seeds.

Therefore, this study was carried out to compare the effect of applied mineral phosphorus with seed inoculation with the biofertilizer phosphorein on growth, photosynthetic pigments, total sugars in leaves, yield and yield components, seed quality, and anatomical structure of 'Giza 35' soybean. The ultimate objective was to increase productivity of this important crop and reduce environmental pollution caused by the extensive application of mineral fertilizers.

\section{MATERIALS AND METHODS}

A field experiment was conducted at Giza Experimental Station, Agricultural Research Center (ARC), during 2005 and 2006 summer seasons to investigate the influence of seed inoculation with phosphate dissolving bacteria (PDB) and phosphorus fertilization on growth, growth analysis traits, anatomical structure of vegetative organs, photosynthetic pigments and total sugars of leaves, yield and yield components as well as seed chemical composition of soybean cv.'Giza 35' (maturity group III).

Physical and chemical properties of the experimental soil in the two seasons are shown in Table (1).

Table 1. Mechanical and chemical soil analysis of the experimental Site in 2005 and 2006 seasons

\begin{tabular}{|l|c|c|}
\hline \multicolumn{1}{|c|}{ Soil properties } & First season (2005) & Second season (2006) \\
\hline Mechanical (\%) & & \\
\hline Coarse sand & 3.28 & 3.48 \\
\hline Fine sand & 28.33 & 28.21 \\
\hline Silt & 30.78 & 31.57 \\
\hline Clay & 37.61 & 36.74 \\
\hline Texture class & Clay loam & Clay loam \\
\hline Chemical: & & 7.56 \\
\hline pH & 7.45 & 1.39 \\
\hline Organic matter (\%) & 1.26 & \\
\hline Available (ppm) & & 53.0 \\
\hline $\mathrm{N}$ & 51.0 & 8.9 \\
\hline P & 8.5 & 481.0 \\
\hline $\mathrm{K}$ & 486.0 & \\
\hline
\end{tabular}


Soybean seed was kindly supplied by the Food Legumes Research Department, FCRI, ARC, Giza, Egypt. Seed was inoculated with Bradyrhizobium japonicum at a rate of $5 \mathrm{~g} / 1 \mathrm{~kg}$ of seed prior to sowing, using a $20 \%$ gum Arabic solution as adhesive. The rhizobium inoculated seed was divided into two equal parts thenafter. One part was subjected to inoculation with a biofertilizer (phosphate dissolving bacteria) at a rate of $10 \mathrm{~g} / \mathrm{k} n$ of seed, whereas the other part was left without biofertilizer treatment.

rhosphorus fertilizer was applied to the soil at sowing in the form of calcium super-phosphate $\left(15.5 \% \mathrm{P}_{2} \mathrm{O}_{5}\right)$ at levels of $0.00,5.63,11.25$ and $22.50 \mathrm{~kg} \mathrm{P}_{2} \mathrm{O}_{5} / \mathrm{fed}$ equivalent to $0,25,50$ and $100 \%$ of the recommended dose, respectively.

w. The experiment was laid out in a split plot design with four replicates. Phosphorus fertilizer levels occupied the main plots, while subplots were devoted to inoculation treatments. Subplot size was $12 \mathrm{~m}^{2}$ (five ridges, four meters long and 60 $\mathrm{cm}$ apart).

.

Treated and untreated seed was sown in hills $15 \mathrm{~cm}$ apart. Sowing took place on 15 May in the two seasons. Three weeks after planting, seedlings were thinned at two plants per hill to achieve the recommended population density .Nitrogen fertilizer at the rate of $15 \mathrm{~kg} \mathrm{~N} / \mathrm{fed}$ in the form of ammonium nitrate $(33.5 \% \mathrm{~N})$ and potassium fertilizer at the rate of $24 \mathrm{~kg} \mathrm{~K}_{2} \mathrm{O} /$ fed in the form of potassium sulphate $\left(48 \% \mathrm{~K}_{2} \mathrm{O}\right)$ were added just before the first irrigation. All other cultural practices were carried out as recommended.

\section{Data collected}

A- Vegetative growth traits

A random sample of five plants was taken from each subplot 90 days after planting to measure plant height $(\mathrm{cm})$, number of branches per plant, and shoot dry weight (g) per plant. For dry weight determination, plant shoot was dried at $70{ }^{\circ} \mathrm{C}$ in an electric oven to a constant weight.

\section{B- Growth analysis}

Four growth stages were assigned for this purpose, viz. 45, 60, 75 and 90 days after sowing. At each growth stage, a random sample of five plants was taken from each subplot. Data recorded on individual plant basis were leaf area $\left(\mathrm{cm}^{2}\right)$ and shoot dry weight $(\mathrm{g})$. The following formulae according to Hunt (1990) were used: 
1) Leaf area index (LAI)

Leaf area in $\mathrm{cm}^{2} /$ plant / Ground area occupied by the plant in $\mathrm{cm}^{2}$

\section{2) Net assimilation rate (NAR), in $\mathrm{mg} / \mathrm{cm}^{2} /$ week}

$\left(\log A_{2}-\log A_{1}\right)\left(W_{2}-W_{1}\right) /\left(A_{2}-A_{1}\right)\left(T_{2}-T_{1}\right)$

\section{Crop growth rate (CGR), in g/ week}

$\left(W_{2}-W_{1}\right) /\left(T_{2}-T_{1}\right)$

Where:

$\left(A_{2}-A_{1}\right)$ : difference in leaf area $\left(\mathrm{cm}^{2}\right)$ between two successive samples.

$\left(\mathrm{W}_{2}-\mathrm{W}_{1}\right)$ : difference in dry matter accumulated between two successive samples.

$\left(T_{2}-T_{1}\right)$ : number of weeks between two successive samples.

The NAR and CGR characters were estimated for the three growth periods of 45-60, 60-75 and 75-90 days after sowing.

C- Anatomical studies:

For anatomical investigation, specimens of selected treatments were taken during the second season (2006) from the median part of the seventh internode on the main stem and from the blade of the terminal leaflet of the seventh trifoliate leaf developed on the main stem at the age of 10 weeks. Specimens were killed and fixed for at least 48 hours in F.A.A. (10 ml formalin, $5 \mathrm{ml}$ glacial acetic acid and $85 \mathrm{ml}$ ethyl alcohol 70\%). The selected materials were washed in $50 \%$ ethyl alcohol, dehydrated in a normal butyl alcohol series, embedded in paraffin wax of $56^{\circ} \mathrm{C}$ melting point, sectioned to a thickness of 20 microns, double stained with crystal violet- erythrosine, cleared in xylene and mounted in Canada balsam (Nassar and El-Sahhar, 1998). Sections were examined to detect histological manifestations of the chosen treatments and photomicrographed.

D- Photosynthetic pigments and total sugars

Photosynthetic pigments and total sugars ( $\mathrm{mg} / \mathrm{g}$ fresh weight) were determined quantitatively at the third full developed upper-most leaf on the main stem at 70 days after sowing in the second season, 2006.

1- Photosynthetic pigments were extracted by aceton $85 \%$. Absorbancy readings for chlorophyll a (cbl a), chlorophyll b (chl b), total chlorophyll (chl $a+b)$ and carotenoides $(\mathrm{C})$ were measured by spectrophotometer at wavelength 663 and $645 \mathrm{~nm}$ for chlorophylls, and at wavelength $452 \mathrm{~nm}$ for carotenoides (A.O.A.C., 1990). 
2- Total sugars was determined using picric acid method according to Shaffer and Hartman as described in (A.O.A.C., 1990).

E- Yield traits

At harvest (116 days after sowing) a random sample of 10 plants was taken from the two central ridges in each subplot to estimate number of pods per plant. Weight of 100 seeds $(\mathrm{g})$ and seed yield per fed were estimated on subplot basis from the same two central ridges,

F- Chemical constituents of the seed (seed quality)

Harvested seed samples of the second season were subjected to chemical analysis to determine: seed crude protein by micro-kiẹldahal ṃethod, (total nitrogen multiplied by 6.25) according to A.O.A.C., 1990. Oil percentage, according to (A.O.A.C., 1990). Total carbohydrates, as glucose (\%) according to Dubois et al. (1956). The method used for phosphorus determination was that described by Moore and Chapman (1986). Sodium" and potassium 'were determined using Flamphotometric method as described in (A.O.A.C., 1990).

\section{Statistical analysis}

The obtained data were subjected to appropriate statistical analysis and the means were compared using L.S.D. at 0.05 level (Steel and Torrie, 1980).

\section{RESULTS·AND DISCUSSION}

\section{I- Growth traits}

Results in Table (2) show that increasing phosphorus fertilizer level significantly increased plant height, branches number and shoot dry weight per plant in both seasons. Similar beneficial effect of applied phosphorus on soybean growth was reported by Hassan et al. (1988), Kabesh et al. (1989),Abd El-Lateef et al. (1998) and Abdel-Aziz and El-Shafie (2005).

Data presented in Table (2) indicate also that seed treatment with phosphorein resulted in significant increases in the investigated growth traits compared with untreated seed in both seasons. Such effect could be attributed to the fact that phosphate solubilizing bacteria play a fundamental role in correcting the phosphorus solubility problem in soil by converting. 
Table. 2. Growth traits of soybean at 90 days after sowing as ffected by phosphorus fertilizer levels with or without biofertilizer treatments in 2005 and 2006 seasons.

\begin{tabular}{|c|c|c|c|c|c|c|c|}
\hline$\therefore \quad$ Trea & ment & \multicolumn{2}{|c|}{$\begin{array}{l}\text { Plant height } \\
\qquad(\mathrm{cm})\end{array}$} & \multicolumn{2}{|c|}{ No. of branches/plant } & \multicolumn{2}{|c|}{$\begin{array}{c}\text { Dry weight of shoot } \\
\text { (g/plant) }\end{array}$} \\
\hline \multirow{2}{*}{$\begin{array}{l}\text { Phosphorus } \\
\text { fertilizer }\end{array}$} & \multirow{2}{*}{ Biofertilizer } & \multicolumn{2}{|c|}{ Seasons } & \multicolumn{2}{|c|}{ Seasons } & \multicolumn{2}{|c|}{ Seasons } \\
\hline & & 2005 & 2006 & 2005 & 2006 & 2005 & 2006 \\
\hline \multirow{3}{*}{$0 \%$} & - & 53.6 & 59.0 & 2.00 & 2.25 & 70.91 & 71.53 \\
\hline & + & 64.8 & 70.4 & 2.25 & 2.50 & 76.25 & 78.49 \\
\hline & Mean & 59.2 . & 64.7 & 2.13 & 2.38 & 73.58 & 75.01 \\
\hline \multirow{3}{*}{$25 \%$} & - & 66.4 & 69.7 & 2.25 & 3.00 & 77.82 & 81.76 \\
\hline & + & 76.9 & 83.1 & 3.25 & 3.25 & 86.26 & 89.84 \\
\hline & Mean & 71.7 & 76.4 & 2.75 & 3.13 & 82.04 & 85.80 \\
\hline \multirow{3}{*}{$50 \%$} & - & 78.2 & 82.9 & 3.00 & 3.25 & 86.72 & 93.06 \\
\hline & + & 87.3 & 91.5. & 3.50 & 4.00 & 100.48 & 101.92 \\
\hline & Mean & 82.8 & 87.2 & 3.25 & 3.63 & 93.60 & 98.99 \\
\hline \multirow{3}{*}{$100 \%$} & - & 88.6 & 93.7 & 3.75 & 4.00 & 101.64 & 105.17 \\
\hline & + & 95.2 & 98.9 & 4.25 & 4.50 & 112.37 & 117.22 \\
\hline & Mean & 91.9 & 96.3 & 4.00 & 4.25 & 107.01 & $111 . .20$ \\
\hline \multicolumn{6}{|c|}{ 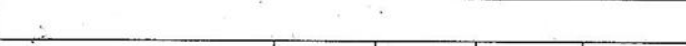 } & & \\
\hline \multicolumn{2}{|c|}{ Mean of uninoc. Seed } & 71.7 & 76.3 & 2.75 & 3.13 & 84.27 & 87.88 \\
\hline \multicolumn{2}{|c|}{ Mean of inoc. seed } & 81.1 & 86.0 & 3.31 & 3.56 & 93.84 & 97.62 \\
\hline \multicolumn{8}{|c|}{ L.S.D. $\quad 0.05$ for } \\
\hline \multicolumn{2}{|c|}{ Phosphorus fertilizer (A) } & 5.33 & 4.74 & 0.28 & 0.25 & 6.25 & 5.79 \\
\hline Biofertilizer & (B). & 4.29 & 3.75 . & 0.20 & 0.17 & 4.57 & 4.18 \\
\hline Interaction & $(A \times B)$ & 7.18 & 6.26 & 0.39 & 0.33 & 8.13 & 7.85 . \\
\hline
\end{tabular}

The fixed form to a soluble one ready for plant nutrition (El-Kalla et al., 1997). The increase in growth traits of soybean plant due to biofertilization treatment were 13.11 and $12.71 \%$ for plant height, 20.36 and $13.74 \%$ for number of branches per plant, 11.36 and $11.08 \%$ for dry weight of shoot per plant in the first and second season, respectively. The present findings are in accordance with those obtained by Abd El-Lateef et al. (1998) on soybean, El-Kalla et al. (1997) and Abdel-Aziz (2005) on faba bean as well as Abdo (2003) on mungbean.

The applied phosphorus and phosphorein biofertilizer interaction significantly affected all the studied growth traits in both seasons. Plant height, branch number, 
and shoot dry weight per plant were remarkably increased with increasing applied-P level either with or without phosphorein biofertilizer, being maximal with the application of the full dose of $-\mathrm{P}$ along with phosphorein. This interaction also revealed that using half the recommended dose of $-P$ along with phosphorein biofertilizer produced similar results to those obtained from application of the full recommended dose, indicating that $50 \%$ of the amount of $-\mathrm{P}$ fertilizer presently used on soybean fields could be saved.

\section{II- Growth analysis}

1) Leaf area index (LAI)

Data in Table (3) show that in both seasons, leaf area index increased with increasing plant age up to 90 days after sowing (DAS). Increasing the level of applied phosphorus significantly increased leaf area index at 45,60,75and 90DAS in both seasons. Similar results were also reported by Abdel-Aziz and El-Shafie (2005) on soybean as well as El-Naggar (1998), Hessien (2000) and Abdo (2003) on mungbean.

Concerning the effect of biofertilizer, results also revealed that biofertilization with phosphate dissolving bacteria gave significant increases in leaf area index at all growth ages. These results are in full accordance with those of Abdo (2003) on mungbean and Abdel- Aziz (2005) on faba bean.

The interaction between applied phosphorus and phosphorein biofertilizer had a significant effect on LAI .At all growth ages, LAI increased with increasing applied -P level either alone or along with the phosphate dissolving bacteria, being maximal from the combination of the full dose of applied -P along with phosphorein biofertilizer. The present results are in accordance with those obtained by Abdo (2003) on mungbean. 
Table 3.Leaf area index (LAI) of soybean at different growth stages as affected by phosphorus fertilizer levels along with or without biofertilizer treatments in 2005 and 2006 seasons.

\begin{tabular}{|c|c|c|c|c|c|c|c|c|c|}
\hline \multicolumn{2}{|c|}{ Treatment } & \multirow{2}{*}{\multicolumn{4}{|c|}{ First seson of 2005}} & \multirow{2}{*}{\multicolumn{4}{|c|}{ Second seson of 2006}} \\
\hline \multirow{3}{*}{$\begin{array}{c}\text { Phosphorus } \\
\text { fertilizer }\end{array}$} & \multirow{3}{*}{ Biofertilizer } & & & & & & & & \\
\hline & & \multicolumn{4}{|c|}{ Plant age (in days) } & \multicolumn{4}{|c|}{ Plant age (in days) } \\
\hline & & 45 & 60 & 75 & 90 & 45 & 60 & 75 & 90 \\
\hline$\cdots$ & - & 1.262 & 3.309 & 5.053 & 6.807 & 1.404 & 3.438 & 4.931 & 7.147 \\
\hline $0 \%$ & + & 1.619 & 3.874 & 5.547 & 7.368 & 1.859 & 3.919 & 5.522 & 7.939 \\
\hline & Mean & 1.441 & 3.592 & 5.300 & 7.088 & 1.632 & 3.679 & 5.227 & 7.543 \\
\hline \multirow{3}{*}{$25 \%$} & - & 1.732 & 3.92 .9 & 5.661 & 7.496 & 1.982 & 4.147 & 5.798 & 8.164 \\
\hline & & 2.204 & 4.698 & 6.429 & 8.924 & 2.636 & 5.053 & 7.036 & 9.352 \\
\hline & Mean & 1.968 & 4.314 & 6.045 & 8.210 & 2.309 & 4.600 & 6.417 & 8.758 \\
\hline \multirow{3}{*}{$50 \%$} & - & 2.349 & 4.957 & 6.612 & 9.207 & 2.789 & 5.242 & 6.898 & 9.728 \\
\hline & + & 2.953 & 5.811 & 7.602 & 10.653 & 3.638 & 6.476 & 8.396 & 11.256 \\
\hline & Mean & 2.651 & 5.384 & 7.107 & 9.930 & 3.214 & 5.859 & 7.647 & 10.492 \\
\hline \multirow{3}{*}{$100 \%$} & - & 3.147 & 5.962 & 7.747. & 10.849 & 3.809 & 6.378 & 8.104 & 11.542 \\
\hline & + & 3.982 & 6.475 & 8.491 & 11.947 & 4.582 & 7.372 & 8.826 & 12.234 \\
\hline & Mean & 3.565 & 6.219 & 8.119 & 11.398 & 4.196 & 6.875 & 8.465 & 11.888 \\
\hline \\
\hline \multicolumn{2}{|c|}{ Mean of uninoc. Seed } & 2.123 & 4.539 & 6.268 & 8.590 & 2.496 & 4.801 & 6.433 & 9.145 \\
\hline \multicolumn{2}{|c|}{ Mean of inoc. seed } & 2.690 & 5.215 & 7.017 & 9.723 & 3.179 & 5.705 & 7.445 & 10.195 \\
\hline \multicolumn{10}{|c|}{ L.S.D. $\quad 0.05$ for } \\
\hline \multicolumn{2}{|c|}{ Phosphorus fertilizer (A) } & 0.249 & 0.338 & 0.359 & 0.405 & 0.317 & 0.348 & 0.429 & 0.483 \\
\hline Biofertilizer & (B) & 0.198 & 0.263 & 0.277 & 0.322 & 0.256 & 0.282 & 0.352 & 0.377 \\
\hline $\begin{array}{l}\text { Interaction } \\
\text { B) }\end{array}$ & $(A X$ & 0.326 & 0.447 & 0.482 & 0.531 & 0.422 & 0.469 & 0.568 & 0.647 \\
\hline
\end{tabular}

2 Net assimilation rate (NAR)

In both seasons, net assimilation rate (NAR) was increased with increasing plant age, being maximal as the second growth period ( $60-75$ days after sowing) and sharply decreased thenafter (Table 4). These results could be ascribed to the higher rate of dry matter accumulation in proportion to the rate of increase in leaf area in the second period. However, the sharp decline in NAR observed in the third period may be attributed to less accumulation rate of dry matter in proportion to the high rate of increase in leaf area. This may be due to shading caused by the upper fully expanded leaves that did not allow light to penetrate to the lower ones. The present findings 
may explain that the second period (60 - 75 DAS) seemed to be the most important growth period for scybean.

Differences in NAR due to the application of phosphorus or biofertilization with phosphorein either separately or in combinations (Table 4) did reach the level of significance at all growth stages, except at the first growth stage (45-60 DAS). NAR tended to decrease with $-\mathrm{P}$ application, biofertilization and their combination. The present results are in general agreement with those. obtained by Abdo (2003) on mungbean.

3 Crop growth rate (CGR)

Results in Table (4) show that the values of CGR were generally higher in the second and third soybean growth stages compared with the first one in both seasons. It is realized that increasing the level of applied phosphorus led to significant increases in CGR at all growth stages. In this connection, El-Naggar (1998) and Abdo (2003) on mungbean plants found that the values of CGR were increased with increasing phosphorus fertilizer level up to $100 \%$ of the recommended dose, being in agreement with the present findings.

Likewise, inoculated soybean seeds with phosphorein biofertilizer significantly increased CGR values at the three growth stages in the two growing seasons. Such results are in harmony with those of Abdo (2003) on mungbean.

The interaction between phosphorus fertilizer and phosphorein biofertilizer had a significant effect on the second and third growth stages in both seasons.CGR was remarkably increased with increasing applied $-P$ level either alone or along with phosphorein biofertilizer, being maximal when the full dose of - $\mathrm{P}$ was combined with biofertilizer. This interaction showed also that $50 \%$ of the recommended dose of - $P$ along with biofertilizer treatment gave significantly similar CGR values to those obtained from the application of the whole dose of - $\mathrm{P}$ alone. 
Table 4. Net assimilation rate (NAR) and crop growth rate (CGR) at different growth stages as affected by applied phosphorus with or without biofertilizer treatments in 2005 and 2006 seasons.

\begin{tabular}{|c|c|c|c|c|c|c|c|c|c|c|c|c|c|}
\hline \multicolumn{2}{|c|}{ Treatment } & \multirow{2}{*}{\multicolumn{6}{|c|}{$\begin{array}{l}\text { Net assimilation rate (NAR, } \\
\mathrm{mg} / \mathrm{cm}^{2} / \text { week) }\end{array}$}} & \multirow{2}{*}{\multicolumn{6}{|c|}{ Crop growth rate (CGR, g/week) }} \\
\hline \multirow{4}{*}{$\begin{array}{l}\text { Phosphorus } \\
\text { fertilizer }\end{array}$} & \multirow{4}{*}{ Biofertilizer } & & & & & & & & & & & & \\
\hline & & \multirow{2}{*}{\multicolumn{3}{|c|}{$\begin{array}{c}\text { First seson of } 2005 \\
\begin{array}{c}\text { Growth periods in } \\
\text { days }\end{array}\end{array}$}} & \multirow{2}{*}{\multicolumn{3}{|c|}{$\begin{array}{c}\text { Second seasons of } \\
2006 \\
\begin{array}{c}\text { Growth periods in } \\
\text { days }\end{array} \\
\end{array}$}} & \multirow{2}{*}{\multicolumn{3}{|c|}{\begin{tabular}{c|}
$\begin{array}{c}\text { First seson of } \\
2005\end{array}$ \\
$\begin{array}{c}\text { Growth periods in } \\
\text { days }\end{array}$ \\
\end{tabular}}} & \multirow{2}{*}{\multicolumn{3}{|c|}{$\begin{array}{c}\text { Second seasons of } \\
2006 \\
\begin{array}{c}\text { Growth periods in } \\
\text { days }\end{array}\end{array}$}} \\
\hline & & & & & & & & & & & & & \\
\hline & & $\begin{array}{c}45- \\
60\end{array}$ & $\begin{array}{l}60- \\
75\end{array}$ & $\begin{array}{l}75- \\
90\end{array}$ & $\begin{array}{c}45- \\
60\end{array}$ & $\begin{array}{c}60- \\
75\end{array}$ & $\begin{array}{l}75- \\
90\end{array}$ & $\begin{array}{c}45- \\
60\end{array}$ & $\begin{array}{l}60- \\
75\end{array}$ & $\begin{array}{l}75- \\
90\end{array}$ & $\begin{array}{c}45- \\
60 \\
\end{array}$ & $\begin{array}{c}60- \\
75\end{array}$ & $\begin{array}{c}75- \\
90\end{array}$ \\
\hline \multirow{3}{*}{$0 \%$} & - & 6.571 & 7.220 & 4.726 & 6.550 & 7.553 & 4.329 & 6.28 & 13.39 & 12.62 & 6.50 & 14.07 & 11.63 \\
\hline & + & 5.928 & 6.995 & 4.416 & 5.777 & 7.248 & 4.224 & 6.81 & 14.51 & 12.75 & 7.29 & 15.23 & 12.57 \\
\hline & Mean & 6.250 & 7.108 & 4.571 & 6.164 & 7.401 & 4.277 & 6.55 & 13.95 & 12.69 & 6.90 & 14.65 & 12.10 \\
\hline \multirow{3}{*}{$25 \%$} & - & 5.744 & 6.847 & 4.417 & 5.691 & 6.961 & 4.283 & 6.95 & 14.61 & 12.99 & 7.32 & 15.43 & 13.33 \\
\hline & + & 5.186 & 6.145 & 4.206 & 4.837 & 5.779 & 4.170 & 7.69 & 15.26 & 14.40 & 8.18 & 15.58 & 15.28 \\
\hline & Mean & 5.465 & 6.496 & 4.312 & 5.264 & 6.370 & 4.227 & 7.32 & 14.94 & 13.70 & 7.75 & 15.51 & 14.31 \\
\hline \multirow{3}{*}{$50 \%$} & - & 4.861 & 6.048 & 3.919 & 4.671 & 5.847 & 4.293 & 7.64 & 15.64 & 13.90 & 8.12 & 15.96 & 15.94 \\
\hline & + & 5.260 & 5.622 & 4.168 & 3.871 & 5.283 & 4.086 & 8.44 & 16.87 & 16.96 & 8.67 & 17.58 & 17.94 \\
\hline & Mean & 5.061 & 5.835 & 4.044 & 4.271 & 5.565 & 4.190 & 8.04 & 16.26 & 15.43 & 8.40 & 16.77 & 16.94 \\
\hline \multirow{3}{*}{$100 \%$} & - & 3.983 & 5.531 & 4.313 & 3.762 & 5.442 & 4.037 & 7.90 & 16.96 & 17.88 & 8.54 & 17.65 & 17.66 \\
\hline & + & 3.615 & 5.443 & 4.478 & 3.343 & 5.316 & 4.325 & 8.32 & 18.14 & 20.37 & 8.93 & 19.32 & 20.31 \\
\hline & Mean & 3.799 & 5.487 & 4.396 & 3.553 & 5.379 & 4.181 & 8.11 & 17.55 & 19.13 & 8.74 & 18.49 & 18.99 \\
\hline \multicolumn{2}{|c|}{ Mean of uninoc. Seed } & 5.290 & 6.412 & 4.344 & 5.169 & 6.451 & 4.236 & 7.19 & 15.15 & 14.35 & 7.62 & 15.78 & 14.64 \\
\hline \multicolumn{2}{|c|}{ Mean of inoc. seed } & 4.997 & 6.051 & 4.317 & 4.457 & 5.907 & 4.201 & 7.82 & 16.20 & 16.12 & 8.27 & 16.93 & 16.53 \\
\hline \multicolumn{14}{|c|}{ L.S.D. $\quad 0.05$ for } \\
\hline \multicolumn{2}{|c|}{$\begin{array}{l}\text { Phosphorus fertilizer } \\
\text { (A) }\end{array}$} & 0.348 & 0.537 & NS & 0.472 & 0.665 & NS & 0.55 & 0.72 & 0.74 & 0.59 & 0.81 & 0.75 \\
\hline \multicolumn{2}{|l|}{ Biofertilizer } & 0.279 & NS & NS & 0.373 & NS & NS & 0.43 & 0.55 & 0.57 & 0.47 & 0.65 & 0.59 \\
\hline \multicolumn{2}{|l|}{$\begin{array}{l}\text { Interaction } \\
\mathrm{X} B \text { ) }\end{array}$} & 0.457 & NS & NS & 0.624 & NS & NS & NS & 0.94 & 0.97 & NS & 1.06 & 0.98 \\
\hline
\end{tabular}




\section{III- Anatomical studies}

From the above mentioned results of soybean growth as affected by phosphorein biofertilizer under different levels of applied phosphorus, it could be stated that the effect of the recommended dose of applied phosphorus alone (control treatment) did not statistically differ from that of applying half of the recommended dose along with the biofertilizer treatment on growth of soybean. Thus, the anatomical structures of the main stem and leaves of soybean plants that received such treatments were studied.

\section{Anatomy of the main stem}

Microscopical measurements of certain traits in transverse sections through the median part of the seventh internode of the main stem of soybean cv. 'Giza 35', at 10 weeks after sowing, as affected by mineral and bio-fertilizers are given in Table (5). Likewise, microphotographs illustrating the effects of these treatments are shown in Figure (1).

Table 5. Measurements, in micron, of some histological traits in transverse sections through the median part of the seventh internode of the main stem of soybean cv. Giza 35, at the age of 10 weeks, as affected by mineral and biofertilizers.

(Mean of three sections from three specimens)

\begin{tabular}{|l|c|c|c|c|c|}
\hline \multirow{2}{*}{\multicolumn{1}{|c|}{ Trait }} & \multicolumn{5}{c|}{ Treatment } \\
\cline { 2 - 6 } & *Full dose & Half dose of & $\begin{array}{c} \pm \text { to } \\
\text { control }\end{array}$ & $\begin{array}{c}\text { **Half dose of } \\
\mathrm{P}+ \\
\text { biofertilizer }\end{array}$ & $\begin{array}{c} \pm \% \text { to } \\
\text { control }\end{array}$ \\
\hline Stem diameter. & 6152 & 5255 & -14.6 & 6264 & +1.8 \\
\hline Epidermis thickness. & 24 & 21 & -12.5 & 24 & - \\
\hline Cortex thickness. & 206 & 183 & -11.2 & 235 & +14.1 \\
\hline Vascular cylinder thickness. & 1163 & 914 & -21.4 & 1196 & +2.8 \\
\hline Fibrous tissue thickness. & 139 & 148 & +6.5 & 153 & +10.1 \\
\hline Phloem tissue thickness. & 316 & 302 & -4.4 & 332 & +5.1 \\
\hline Xylem tissue thickness. & 708 & 464 & -34.5 & 711 & +0.4 \\
\hline Pith diameter. & 3366 & 3019 & -10.3 & 3354 & -0.4 \\
\hline
\end{tabular}

Fill dose of applied $P=225 \mathrm{~kg} P O$ 作

Biofertilizer = Phosphate dissolving bacteria (phosphorein). 

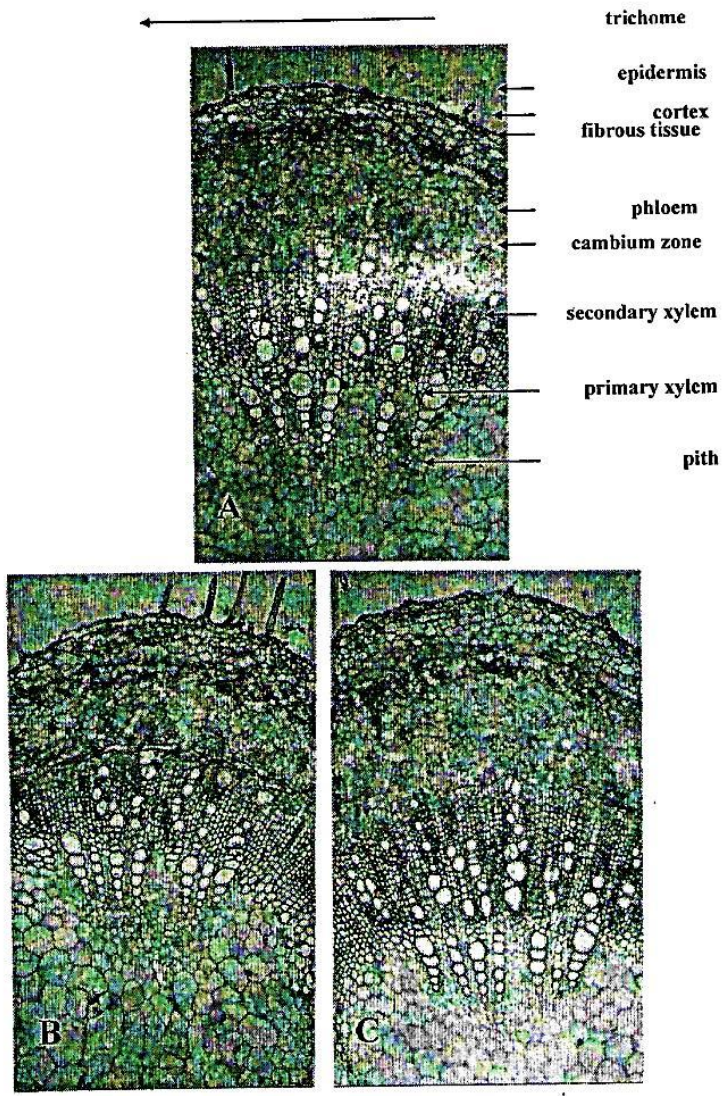

Figure 1. Transverse sections through the seventh internode of the main stem of soybean $\mathrm{cv}$. Giza 35 , at the age of 10 weeks, as affected by mineral and bio-fertilizers .

A- Control (plant received $100 \%$ of the recommended dose of mineral fertilizer from phosphorus).

B- Plant received $50 \%$ of the recommended dose of mineral fertilizer from phosphorus.

C- Plant received $50 \%$ of the recommended dose of mineral fertilizer from phosphorus + biofertilizer treatment with phosphorein . 
It is clear from Table (5) and Figure (1) that soybean plant received $50 \%$ of the recommended dose of phosphorus fertilizer showed a prominent decrease in stem diameter by $14.6 \%$ less than the stem diameter of control plants which received the full recommended dose of phosphorus fertilizer. The decrease in stem diameter of plants that received half the recommended dose could be attributed to the prominent decrease in all included tissues except that of fibrous tissue thickness which showed slight increase of $6.5 \%$ over the control. The decreases below the control were $12.5 \%$ for epidermis thickness, $11.2 \%$ for cortex thickness, $21.4 \%$ for vascular cylinder thickness, $4.4 \%$ for phloem tissue thickness, $34.5 \%$ for xylem tissue thickness and $10.3 \%$ for pith diameter.

Results also revealed that the use of biofertilizer along with $50 \%$ of the recommended dose of phosphorus fertilizer gave a slight increase in stem diameter $(1.8 \%)$ compared with the full dose of phosphorus fertilizer along, although a negligible decrease $(0.4 \%)$ in pith diameter was observed. The increment in stem diameter could be attributed to the different degrees of increments in thickness of mest of the included tissues. Such increments were $14.1 \%$ for cortex, $2.8 \%$ for vascular cylinder, $10.1 \%$ for fibrous tissue, $5.1 \%$ for phloem tissue and $0.4 \%$ for xylem tissue.

\section{Anatomy of the leaf}

Microscopical measurements of certain traits in transverse sections through the blade of terminal leaflet of the seventh trifoliate leaf on the main stem of soybean plant cv. 'Giza 35', at the age of 10 weeks, as affected by phosphorus fertilizer and biofertilizer phosphorein are presented in Table (6). Also, microphotographs illustrating the effects of these treatments are given in Figure (2).

It is obvious from Table (6) and Figure (2) that soybean plants that received $50 \%$ of the recommended dose of applied phosphorus showed prominent reductions in thickness of midvein and lamina of the assigned leaflet by 16.0 and $41.5 \%$ compared with the control plants receiving the full recommended dose of phosphorus, respectively. The thinner leaflets induced by the median level $(50 \%)$ of phosphorus fertilizer could be attributed to the decrease in thickness of palisade and spongy tissues as well as in dimensions and components of the main vascular bundle of midrib region. Decreases below the control were 43.9, 44.5, 25.8 and $15.6 \%$ for the thickness of palisade tissue, thickness of spongy tissue, length of midvein bundle and width of midvein bundle, respectively. Also, number of vessels per midvein bundle and vessel diameter were decreased by 9.6 and $4.2 \%$ less than those in leaves of control plants, respectively. 
A

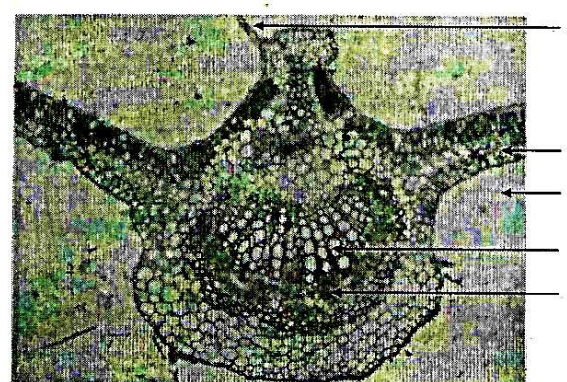

trichome

palisade tissue spongy tissue

xylem

phloem

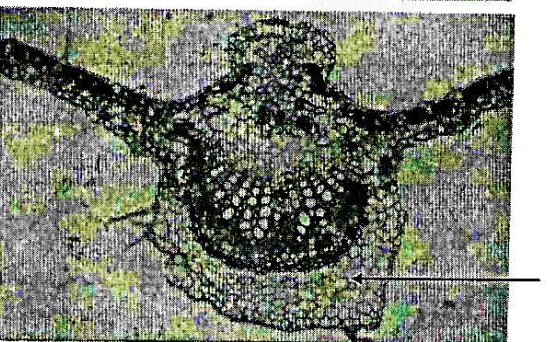

ground tissue

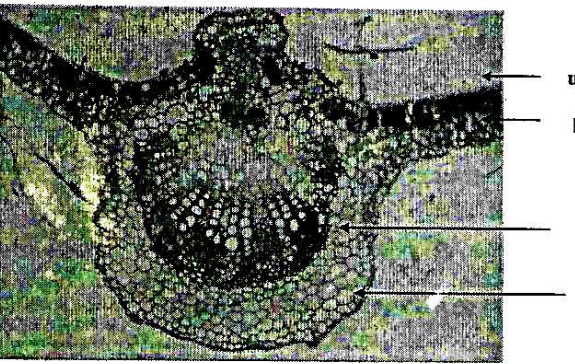

upper epidermis

lower epidermis

midvein bundle

C

midrib region

Figure 2. Transverse sections through the blade of terminal leaflet of the seventh compound leaf developed on the main stem of soybean cr. Giza 35, at the age of 10 weeks, as affected by mineral and bio-fertilizers. (X.52)

A- Control (plant received $100 \%$ of the recommended dose of mineral fertilizer from phosphorus).

B- Plant received $50 \%$ of the recommended dose of mineral fertilizer from phosphorus.

C- Plant received $50 \%$ of the recommended dose of mineral fertilizer from phosphorus + biofertilizer treatment with phosphorein . 
1000 EFFECT OF PHOSPHATE DISSOLVING BACTERIA INOCULATION AND PHOSPHORUS FERTILZATION ON GROWTH, YIELD AND SEED QUALTTY OF SOYBEAN

Table 6. Counis and measurements, in micron, of some histological traits in transverse sections through the blade of the terminal leaflet of the seventh trifoliate leaf on the main stem of soybean cv. Giza 35, at the age of 10 weeks, as affected by mineral and biofertilizers

(Mean of three sections from three specimens)

\begin{tabular}{|c|c|c|c|c|c|}
\hline \multirow{2}{*}{\begin{tabular}{|lll} 
& & \\
& Trait \\
& & \\
\end{tabular}} & \multicolumn{2}{|c|}{$\therefore \quad \therefore \quad$} & Treatment & \multicolumn{2}{|c|}{$\therefore$} \\
\hline & $\begin{array}{l}\text { *Full dose of } \\
P \text { (control) }\end{array}$ & $\begin{array}{c}\text { Half dose } \\
\text { of } P\end{array}$ & $\begin{array}{l} \pm \% \text { to } \\
\text { control }\end{array}$ & $\begin{array}{c}\text { **Half dose of } \\
\dot{\mathrm{p}}+ \\
\text { biofertilizer }\end{array}$ & $\begin{array}{l} \pm \% \text { to } \\
\text { control }\end{array}$ \\
\hline Midvein thickness. & 1837 & 1543 & -16.0 & 1788 & -2.7 \\
\hline Lamina thickness. & 294 & 172 & -41.5 & 297 & +1.0 \\
\hline Palisade tissue thickness. & 132 & 74 & -43.9 & 135 & +2.3 \\
\hline Spọngy tisšue thiçkness. & 137 & 76 & -44.5 & 138 & +0.7 \\
\hline $\begin{array}{l}\text { Dimensions of the main vascular } \\
\text { bundle of midvein: }\end{array}$ & $\therefore$ & & $\vdots$ & . & \\
\hline Length & 561 & 416 & -25.8 & 502 & -10.5 \\
\hline Width & 982 & 829 & -15.6 & 961 & -2.1 \\
\hline No, of vessels/midvein bundle. & 52 & 47 & -9.6 & 59 & +13.5 \\
\hline Vessel diameter. & 48 & 46 & -4.2 & 42 & -12.5 \\
\hline
\end{tabular}

* Full dose of applied- $\mathrm{P}=22.5 \mathrm{~kg} \mathrm{P}_{2} \mathrm{O}_{5} /$ feddan.

**: Biofertilizer $=$ Phosphate dissolving bacteria (phosphorein).

Data also indicated that soybean plants obtained from biofertilization of seeds with phosphate dissolving bacteria (phosphorein) and received half the recommended dose of phosphorus fertilizer showed a slight decrease in midvein thickness $(2.7 \%)$ compared with the control. Such decrement in midvein thickness could be attributed to the decreases observed in length and width of midvein bundle by 10.5 and $2.1 \%$ less than the control, respectively. Although number of vessels per midvein bundle was.increased by $13.5 \%$ over the control, vessel diameter was decreased by $12.5 \%$ less than the control. In contrast, plantsobţained from biofertilized seeds and received half of the recommended dose of phosphorus showed a slight increase in lamina thickness (1\%) more than the control. The increase in lamina thickness could be attributed to the increment in palisade tissue thickness as well as in spongy tissue thickness by 2.3 and $0.7 \%$ more than the control, respectively. 
These results are generally in harmony with those obtained by Ramadan et al. (2003) on sugar beet and Hassan et al. (2006) on moghat leaves.

\section{IV- Photosynthetic pigments and total sugars}

Results in Table (7) indicate that increasing level of phosphorus fertilization from $25 \%$ up to $100 \%$ of the recommended dose induced significant improvement in concentrations of chl $\mathrm{a}$, chl b, chl $(\mathrm{a}+\mathrm{b})$ and carotenoides as well as total sugars. Increasing the rate of applied phosphorus from 25 to $100 \%$ of the recommended dose gave significant increases of $27.6 \%$ for chlorophyll a, $50.9 \%$ for chlorophyll b, $33.4 \%$ for chlorophyll $(\mathrm{a}+\mathrm{b}), 36.8 \%$ for carotenoides and $45.5 \%$ for total sugars in leaves of soybean. These findings may prove the role of phosphorus in stimulating chlorophyll synthesis through encouraging pyridoxal phosphate enzyme formation which plays an important role in a-amino levulinic acid synthetase as a primary compound in chlorophyll synthesis. Abdel-Aziz and El-Shafie (2005) stated that foliar spray of -P caused a relative increase in total chlorophyll of soybean plant leaves in comparison with untreated plants and the effect of concentration of $3 \% \quad \mathrm{P}_{2} \mathrm{O}_{5}$ was more pronounced than that of $1.5 \% \mathrm{P}_{2} \mathrm{O}_{5}$, being in general agreement with accordance with the present findings. In this respect, Abdo (2003) recorded significant increases in concentrations of $\mathrm{chl} \mathrm{a}$, chl b and total chlorophyll in leaves of mungbean with increasing the rate of phosphorus fertilizer from 7.75 to $23.25 \mathrm{~kg} \mathrm{P}_{2} \mathrm{O}_{5} /$ fed., being in accordance with the present findings.

Data in Table (7) also revealed that phosphorein biofertilizer caused significant increases in chl a, chl b, chl $(\mathrm{a}+\mathrm{b})$ and carotenoides as well as total sugars of soybean leaves by $14.62,20.39,16.09,18.59$ and $16.67 \%$ compared with no phosphorein, respectively. In this connection Abdo (2003) recorded significant increases in chlorophyll content in mungbean plant leaves by u-ing phosphorein biofertilizer.

The interaction between levels of phosphorus fertilization and biofertilizer phosphorein had a significant effect on all physiological traits under investigation. It is observed that the highest values for photosynthetic pigments and total sugars in leaves were recorded at the full dose of phosphorus fertilizer combined with biofertilizer phosphorein. The highest values were $2.946 \mathrm{mg} / \mathrm{g} \mathrm{FW}$ for chlorophyll a, $1.204 \mathrm{mg} / \mathrm{g}$ FW for chlorophyll b, $4.146 \mathrm{mg} / \mathrm{g}$ FW for total chlorophyll (a+b), 0.225 $\mathrm{mg} / \mathrm{g} \mathrm{FW}$ for carotenoides and $8.797 \mathrm{mg} / \mathrm{g}$ FW for total sugars. Increasing level of applied phosphorus or using phosphorein without increasing the level of mineral - fertilizer produced significant increases in all physiological traits under investigation. It is obvious that the use of phosphorein biofertilizer could substitute half the recommended dose of applied phosphorus fertilizer. Similar results were reported by Abdo (2003) on mungbean plants. 
1002 EFFECT OF PHOSPHATE DISSOLVING BACTERIA INOCULATION AND PHOSPHORUS FERTILIZATION ON GROWTH, YIELD AND SEED QUALTYY OF SOYBEAN

Table 7. Effect of biofertilizer treatment on photosynthetic pigments and total sugars in leaves of soybean cv.'Giza 35'at 70 days age, grown under different levels of phosphorus fertilization in 2006 season.

\begin{tabular}{|c|c|c|c|c|c|c|}
\hline \multicolumn{2}{|c|}{ Treatment } & \multicolumn{4}{|c|}{$\begin{array}{l}\text { Photosynthetic pigments } \\
\mathrm{mg} / \mathrm{g} \mathrm{FW}\end{array}$} & \multirow{2}{*}{$\begin{array}{c}\text { Total sugars } \\
\mathrm{mg} / \mathrm{g} \mathrm{FW}\end{array}$} \\
\hline $\begin{array}{c}\text { Phosphorus } \\
\text { fertilizer }\end{array}$ & Biofertilizer & Chl a & Chl b & $\mathrm{Chl}(\mathrm{a}+\mathrm{b})$ & Carotenoides & \\
\hline \multirow{3}{*}{$0 \%$} & - & 1.522 & 0.629 & 2.149 & 0.118 & 4.335 \\
\hline & + & 1.984 & 0.662 & 2.648 & 0.143 & 5.192 \\
\hline & Mean & 1.753 & 0.646 & 2.399 & 0.131 & 4.764 \\
\hline \multirow{3}{*}{$25 \%$} & - & 2.081 & 0.675 & 2.753 & 0.136 & 5.244 \\
\hline & + & 2.375 & 0.783 & 3.159 & 0.174 & 6.381 \\
\hline & Mean & 2.228 & 0.729 & 2.956 & 0.155 & 5.813 \\
\hline \multirow{3}{*}{$50 \%$} & - & 2.416 & 0.779 & 3.191 & 0.172 & 6.427 \\
\hline & + & 2.729 & 1.058 & 3.783 & 0.196 & 7.769 \\
\hline & Mean & 2.573 & 0.919 & 3.487 & 0.184 & 7.098 \\
\hline \multirow{3}{*}{$100 \%$} & - & 2.738 & 0.996 & 3.738 & 0.198 & 8.114 \\
\hline & + & 2.946 & 1.204 & 4.146 & 0.225 & 8.797 \\
\hline & Mean & 2.842 & 1.100 & 3.942 & 0.212 & 8.456 \\
\hline \multicolumn{7}{|c|}{. } \\
\hline \multicolumn{2}{|c|}{ Mean of uninoc. Seed } & 2.189 & 0.770 & 2.958 & 0.156 & 6.030 \\
\hline \multicolumn{2}{|c|}{ Mean of inoc. seed } & 2.509 & 0.927 & 3.434 & 0.185 & 7.035 \\
\hline \multicolumn{7}{|c|}{0.05 for } \\
\hline \multicolumn{2}{|c|}{ Phosphorus fertilizer (A) } & 0.217 & 0.148 & 0.329 & 0.021 & 1.054 \\
\hline Biofertilizer & (B) & 0.165 & 0.113 & 0.261 & 0.017 & 0.809 \\
\hline Interaction & $(A \times B)$ & 0.268 & 0.182 & 0.402 & 0.026 & 1.295 \\
\hline
\end{tabular}




\section{- V- Yield and yield components}

Results in Table 8 show that increasing the level of applied phosphorus up to $100 \%$ of the recommended dose resulted in remarkable increases in pod number per plant and seed yield per feddan, but the differences between 50 and $100 \%$ of the recommended dose did not reach the level of significance. On the other hand, 100seed weight was not significantly affected by applied-P levels. Yield increases resulting from increasing applied $-\mathrm{P}$ level from 25 to $100 \%$ of the recommended dose were 24.68 and $23.29 \%$ in the first and second seasons, respectively. These results are in accordance with those of Kabesh et al. (1989), El-Awag et al. (1993), Abd El-Lateef et al. (1998) and Abdel-Aziz and El-Shafie (2005) on soybean.

Table 8. Yield and yield components of soybean cv. 'Giza $35^{\prime}$ as affected by different levels of phosphorus fertilizeration with or without biofertilizer treatments in 2005 and 2006 seasons.

\begin{tabular}{|c|c|c|c|c|c|c|c|}
\hline \multicolumn{2}{|c|}{ Treatment } & \multirow{2}{*}{\multicolumn{2}{|c|}{ No. of pods/plant }} & \multirow{2}{*}{\multicolumn{2}{|c|}{$\begin{array}{l}\text { Weight of } 100 \text { seeds } \\
\text { (g) }\end{array}$}} & \multirow{2}{*}{\multicolumn{2}{|c|}{$\begin{array}{l}\text { Seed yield } \\
\text { (t) /feddan }\end{array}$}} \\
\hline \multirow{3}{*}{$\begin{array}{l}\text { Phosphorus } \\
\text { fertilizer }\end{array}$} & \multirow{3}{*}{ Biofertilizer } & & & & & & \\
\hline & & & & - ${ }^{\mathrm{S}}$ & & & \\
\hline & & 2005 & 2006 & 2005 & 2006 & 2005 & 2006 \\
\hline \multirow{3}{*}{$0 \%$} & - & 44.5 & 48.3 & 16.4 & 16.2 & 1.132 & 1.167 \\
\hline & + & 50.9 & 56.1 & 16.8 & 16.5 & 1.276 & 1.283 \\
\hline & Mean & 47.7 & 52.2 & 16.6 & 16.4 & 1.204 & 1.225 \\
\hline \multirow{3}{*}{$25 \%$} & - & 50.8 & 56.2 & 16.7 & 16.6 & 1.255 & 1.292 \\
\hline & + & 57.0 & 62.6 & 16.9 & 17.0 & 1.533 & 1.568 \\
\hline & Mean & 53.9 & $59.4^{-}$ & $\cdot 16.8$ & 16.8 & 1.394 & 1.430 \\
\hline \multirow{3}{*}{$50 \%$} & - & 57.4 & 61.6 & 17.0 & 17.1 & 1.567 & 1.585 \\
\hline & + & 60.8 & 66.5 & 17.3 & 17.2 & 1.720 & 1.744 \\
\hline & Mean & 59.1 & 64.1 & 17.1 & 17.1 & 1.644 & 1.665 \\
\hline \multirow{3}{*}{$100 \%$} & - & 60.6 & 66.6 & 16.8 & 17.1 & 1.731 & 1.737 \\
\hline & + & 64.2 . & 70.0 & 16.9 & 17.0 & 1.745 & 1.788 \\
\hline & Mean & 62.4 & 68.3 & 16.8 & 17.0 & 1.738 & 1.763 \\
\hline \multicolumn{2}{|c|}{ Mean of uninoc. Seed } & 53.3 & 58.2 & 16.7 & 16.8 & 1.421 & 1.445 \\
\hline \multicolumn{2}{|c|}{ Mean of inoc. seed } & 58.2 & 63.8 & 16.9. & 17.0 & 1.569 & 1.596 \\
\hline \multicolumn{8}{|c|}{ - } \\
\hline \multicolumn{2}{|c|}{ Phosphorus fertilizer (A) } & 3.8 & 4.5 & NS & NS & 0.132 & 0.141 \\
\hline Biofertilizer & (B) & 3.1 & 3.5 & NS & NS & 0.103 & 0.112 \\
\hline Interaction & $(A \times B)$ & 5.4 & 6.1 & NS & NS & 0.170 & 0.181 \\
\hline
\end{tabular}


EFFECT OF PHOSPHATE DISSOLVING BACTERIA INOCULATION AND PHOSPHORUS FERTILIZATION ON GROWTH,YIELD AND SEED QUALTYY OF SOYBEAN

Similarly, the effect of biofertilizer \{phosphate dissolving bacteria (PDB)\} on yield and its components (Table 8 ) indicate that inoculated soybean with biofertilizer showed significant increases in seed yield and pod number per plant. However, weigh of 100 -seed was not significantly affected. The increase in seed yield per feddan due to biofertilization was almost $10 \%$ in both seasons. Similar results were obtainẹ by El-Awag et al. (1993) and Abd El-Lateef et al. (1998) on soybean and Abdo (2003) on mungbean, El-Kalla et al. (1997) and Abdel-Aziz (2005) on faba bean.

The applied phosphorus level and seed inoculation with the phosphate dissolving bacteria interaction had a significant effect on yield and its components in both seasons (Table 8).The highest plant pod number and the greatest seed yield per feddan were obtained from the combined application of the full dose of phosphorus along with the phosphate dissolving bacteria, followed by half the dose of phosphorus + PDB and the full dose of phosphorus alone, with no significant differences among the three treatments. These results indicate that $50 \%$ of the recommended dose of phosphorus, presently used in soybean fields could be saved by using PDB as seed treatment. The present results agreed with those reported by El-Awag et al. (1993) and Abd El-Lateef et al. (1998) on soybean, and by El-Kalla et al. (1997) on faba bean, and Abdo (2003) on mungbean.

VI- Chemical constituents of the seed (seed quality)

Seed chemical composition as affected by phosphorein biofertilizer under different levels of phosphorus fertilization is presented in Table (9). 
Table 9. ertain chemical constituents of soybean seeds as affected by seed inoculation with biofertilizer and different levels of phosphorus fertilization in 2006 seasọn.

\begin{tabular}{|c|c|c|c|c|c|c|c|}
\hline \multicolumn{2}{|c|}{ Treatment } & \multirow{2}{*}{$\begin{array}{c}\text { Crude } \\
\text { protein } \\
(\%)\end{array}$} & \multirow{2}{*}{$\begin{array}{l}\text { Oil } \\
(\%)\end{array}$} & \multirow{2}{*}{$\begin{array}{c}\text { Total } \\
\text { carbohydrates } \\
(\%)\end{array}$} & \multirow{2}{*}{$\begin{array}{c}\text { Phosphorus } \\
(\%)\end{array}$} & \multirow{2}{*}{$\begin{array}{l}\text { Sodium } \\
\text { (ppm) }\end{array}$} & \multirow{2}{*}{$\begin{array}{c}\text { Potassium } \\
(\mathrm{ppm})\end{array}$} \\
\hline $\begin{array}{l}\text { Phosphorus } \\
\text { fertilizers }\end{array}$ & $\begin{array}{l}\text { Biofertilizer } \\
.\end{array}$ & & & & & & \\
\hline \multirow[t]{3}{*}{$0 \%$} & - & 28.46 & 24.11 & 25.47 & 0.442 & 0.083 & 0.437 \\
\hline & $\therefore \quad+\quad \therefore$ & 29.85 & 22.45 & 26.99 & 0.476 & 0.085 & 0.443 \\
\hline & Mean & 29.16 & 23.28 & 26.23 & 0.459 & 0.084 & 0.440 \\
\hline \multirow[t]{3}{*}{$25 \%$} & - & 30.97 & 24.05 & 26.85 & 0.544 & 0.087 & 0.443 \\
\hline & + & 33.91 & 22.35 & 28.06 & 0.581 . & 0.087 & 0.442 \\
\hline & Mean & 32.44 & $23.20^{\circ}$ & 27.46 & 0.563 & 0.087 & 0.443 \\
\hline \multirow[t]{3}{*}{$50 \%$} & - & 32.75 & 22.37. & 29.82 & 0.605 & 0.090 & 0.464 \\
\hline & $+\therefore$ & 35.89 & 21.18 & $\because 31: 17$ & 0.646 & 0.100 & 0.454 \\
\hline & Mean & 34.32 & 21.78 & 30.50 & 0.626 & 0.095 & $0.459^{\circ}$ \\
\hline \multirow[t]{3}{*}{$100 \%$} & - & 34.83 & 20.61 & 31.99 & 0.660 & 0.110 & 0.466 \\
\hline & + & 36.69 & 19.73 & 33.29 & 0.665 & 0.108 & 0.464 \\
\hline & Mean & 35.76 & 20.17 & 32.64 & 0.663 & 0.109 & 0.465 \\
\hline \multicolumn{8}{|l|}{ 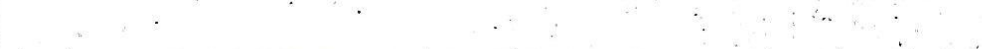 } \\
\hline \multicolumn{2}{|c|}{ Mean of uninoc. Seed } & 31.75 & 22.79 & 28.53 & 0.563 & 0.093 & 0.453 \\
\hline \multicolumn{2}{|c|}{ Mean of inoc. seed } & 34.09 & 21.43 & 29.88 & 0.592 & 0.095 & 0.451 \\
\hline \multicolumn{8}{|c|}{ L.S.D. $\quad 0.05$ for } \\
\hline \multicolumn{2}{|c|}{ Phosphorus fertilizer (A) } & 0.86 & 0.52 & 1.46 & 0.026 & NS & NS \\
\hline Biofertilizer & (B) & 0.61 & 0.37 & 1.03 & 0.018 & NS & NS \\
\hline Interaction & $(A \times B)$ & 1.21 & 0.64 & NS & NS & NS & NS \\
\hline
\end{tabular}

Results indicate that increasing the level of applied phosphorus significantly increased the percentage of seed crude protein, total carbohydrates and phosphorus. Increasing the level of phosphorus fertilizer from 25 to $100 \%$ of the recommended dose gave significant increases of $10.2,18.9$ and $17.8 \%$ for seed crude protein, total 
carbohydrates and phosphorus contents. On the other hand, seed oil content was significantly decreased with increasing the level of phosphorus fertilizer up to $100 \%$ of . the recommended dose. At the same time, the concentrations of sodium and potassium in soybean seeds were not affected by increasing the level of phosphorus fertilizer.

The promoting effect of phosphorus fertilizer on seed crude protein content was also reported by Abd El-Lateef et al. (1998) and Abdel-Aziz and El-Shafie (2005) on soybean, Hessien (2000) and Abdo (2003) on mungbean and Abdel-Aziz (2005) on faba bean, being in agreement with the present findings. Also, Mohammed (2004) on . cowpea stated that phosphorus fertilization increased seed phosphorus percentage.

As for the effect of inoculation with phosphate dissolving bacteria (PDB), dața revealed that such treatment significantly increased the seed crude protein, total carbohydrates and phosphorus by $7.37,4.73$ and $5.15 \%$, respectively. Meanwhile, such treatment significantly decreased the seed oil percentage, but showed no statistical effect on concentrations of sodium and potassium in seeds of soybean cv. 'Giza 35'. In this respect, El-Kalla et al. (1997) stated that phosphorein biofertilizer increased seed protein content of faba bean. Similar results were also reported by Abdo (2003) on mungbean, being in accordance with the present findings.

The interaction between phosphorus fertilizer level and the biofertilizer seed treatment revealed insignificant effect in all characters except for seed protein and oil percentages. The maximum increase in seed protein was recorded at the combined treatment of the full dose of phosphorus fertilizer along with the biofertilizer. In contrast, seed oil percentage was minimal at the same treatment. The findings of Abd El-Lateef et al. (1998) on soybean and Abdo (2003) on mungbean indicated that seed crude protein was increased with phosphorus fertilization along with inoculation with phosphate dissolving bacteria, being in agreement with the present results.

\section{REFERENCES}

1. Abd El-Lateef, E. M., M. M. Selim and T.G. Behairy. 1998. Response of some oil crops to biofertilization with phosphate dissolving bacteria associated with different levels of phosphatic fertilization. Bull. NRC, Egypt., 23 (2): 193-202.

2. Abdel- Aziz, El-Set A. 2005. Effect of phosphorein with different levels of phosphorus fertilizer on faba bean under calcareous soil condition. Minufiy J. Agric. Res., 30 (2):549-563.

3. Abdel-Aziz, El-Set A. and A. I. El-Shafie. 2005. Response of soybean to foliar application of phosphatic fertilizer and some micronutrients. Egypt. J. Appl. Sci., 20 (5B): 696-719. 
4. Abdo, Fatma A. 2003. Effect of biofertilizer with phosphate dissolving bacteria under different levels of phosphorus fertilization on mungbean plant. Zagazig J. Agric. Res., 30 (1): 187-211.

5. A.O.A.C. 1990. Official Methods of Analysis. 15th Ed. Association of Official Agricultural Chemists, Washington D.C., USA.

6. Dubois, M., K. A. Gilles, J. K. Hamilton, P. A. Rebers and F. Smith. 1956. Colorimetric Method for Determination of Sugars and Related Substances Analytical Chemistry, 28 (3): 797-812.

7. El-Awag, T. I., A. M. Hanna and I. M. El-Naggar. 1993. Influence of bio and mineral phosphate fertilization on soybean production and some characters under different levels of soil moisture. Egypt. J. Appl. Sci., 8 (11): 575-594.

8. El-Kalla, S. E., A. K. Mostafa, A. A. Leila and Rokia A. Awad .1997. Mineral and bio-phosphatic fertilization for intercropped faba bean and onion. Egypt. J. Agric. Res., 77 (1): 253-271.

9. El-Naggar, T. B. A. 1998. Effect of nitrogen, phosphorus and Rhizobium inoculation on growth, yield and quality of mungbean crop. M.. Sc. Thesis, Fac. of Agric., Cairo Univ., Egypt.

10. Hassan, H.R., D. M. A. Nassar and M. H. A. Abou- Bakr. 2006. Effect of mineral and biofertilizers on growth, yield components, chemical constituents and anatomical structure of moghat plant (Glossostemon bruguieri Desf.) grown under reclaimed soil conditions: J. Agric. Sci., Mansoura Univ., 31(3): 1433-1455.

11. Hassan, M. Z., A.E. Sharaf and M. S. Eisa. 1988.Effect of inoculation, nitrogen and phosphorus fertilization on nodulation and yield of soybean (Glycine max (L.) Merr.) in the Sudan.Thirteen Iinternational Congress for Statistics, Computer Science, Social and Demographic Research, 225-236.

12. Hessien, A. M. I. 2000. Evaluation of some mungbean varieties under certain agricultural treatments. M. Sc. Thesis, Fac. of Agric., Ain Shams Univ., Egypt.

13. Hunt, R. 1990. Basic Growth Analysis Published by the Academic Division of Unwin Hyman Litd. London., p. 25-72.

14. Kabesh, M. O., A. I. Thalooth and M. H. Taha. 1989. Effect of different phosphatic fertilizers and foliar spraying with zinc on growth and yield of soybean plant. Annals Agric. Sci., Fac. Agric., Ain Shams Univ., Cairo, Egypt. 34: 101-111.

15. Mohammed, S. S. 2004. Integrated approach for rock phosphate- sulfur combined with bio-fertilization in sandy loam soil. Egypt. J. Appl. Sci., 19 (2): 316-333.

16. Moore, P. D. and S. B. Chapman. 1986. Methods in Plant Ecology. Blackwell Scientific Publications, Oxford, London, Edinburgh, 2nd Ed., pp. 344. 
17. Nassar, M. A. and K. F. El-Sahhar. 1998. Botanical Preparations and Microscopy (Microtechnique). Academic Bookshop, Dokki, Giza, Egypt, pp. 219 (In Arabic).

18. Ramadan, B. S. H., H. R. Hassan and Fatma A. Abdo. 2003. Effect of minerals and biofertilizers on photosynthetic pigments, root quality, yield components and anatomical structure of sugar beet (Beta Vulgaris L.) plants grown under reclaimed soils. J. Agric. Sci. Mansoura Unive., 28 (7): 5139-5160.

19. Steel, R. G. D. and J. A. Torrie. 1980. Principles and Procedure of Statistics, 2 nd Ed., Mc Crow Hill Pub., Co., pp. 633. 


\section{تأثير التلقيح بالبكتريا المذيبة للفوسفات والتسميد الفوسفاتى بلى النمو و المحصول وصفات الجودة في فول الصويا}

فاطمة.عبد المنصف عبده

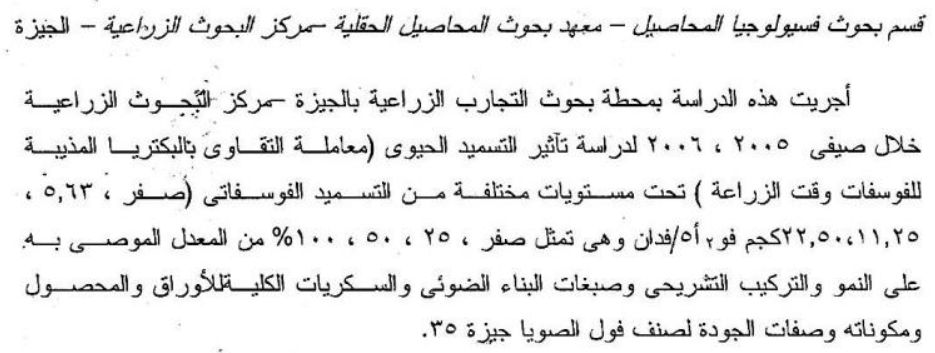

